\title{
Breeding system and pollination of Pleroma trichopodum DC. (Melastomataceae): a potential species for the restoration of Atlantic
} Forest in southern Brazil

\author{
Tiago Simões Malucelli,2* (D), Fabiano Rodrigo Maia² (i) and Isabela Galarda Varassin ${ }^{2}$ (D)
}

Received: March 17, 2018

Accepted: June 5, 2018

\begin{abstract}
Plant-pollinator interactions and their reproductive implications are of central importance to the organization of plant populations and communities in restoration areas. We studied the breeding system and flower visitors of Pleroma trichopodum, a pioneer species of the Atlantic Forest. We attempted to answer three questions: (1) Is P. trichopodum dependent on pollinators and mates for reproduction? (2) What are the pollinators of P. trichopodum? (3) Do tree flower-density and flowering-tree density of $P$. trichopodum enhance the visitation rate of focal trees and their flowers? We tested the breeding system through pollination treatments. We performed focal observations on 10 trees and analyzed the relationship between tree and flower visitation rates, and the tree flower-density and flowering-tree density with Generalized Linear Mixed Models (GLMM). Pleroma trichopodum sets fruits by selfing and outcrossing, both of which occur only through pollinator visits. Bees visited P. trichopodum, and their visitation increased with tree flower-density. Thus, individuals with greater floral displays may function as magnet species, enhancing the pollination of nearby plant species. This characteristic, allied with the ability to reproduce without a mate (selfing) and a tolerance of soggy soils, make P. trichopodum a candidate for Atlantic Forest restoration.
\end{abstract}

Keywords: Atlantic Forest, breeding system, floral density, pioneer, plant-pollinator interactions, Pleroma trichopodum, restoration, selfing

\section{Introduction}

Plant-pollinator interactions and the reproductive outcome of such mutualisms are central to plant population and community organization (Ashman et al. 2004). For this reason, these topics have been intensively studied in a variety of contexts (Ayasse \& Arroyo 2011). Nonetheless, key questions remain unanswered and, for several ecosystems, information is still lacking regarding the reproduction and pollination of most plant species, thus hindering the application of such frameworks to restoration and conservation (Rodrigues et al. 2009; Mayer et al. 2011; Menz et al. 2011).

The restoration of degraded areas is an alternative way of recovering the functionality of ecological systems (Young 2000), and has been used to restore ecosystems threatened by human activities, such as the conversion of tropical forests into pastures (Aide et al. 2000; Cheung et al. 2009). A high proportion of angiosperms depend on animals for their reproduction (Ollerton et al. 2011), while plant persistence is constrained by the breeding system (Bond 1994; Brys \&

1 Part of the under graduation monograph of the first author

2 Laboratório de Interações e Biologia Reprodutiva, Departamento de Botânica, Universidade Federal do Paraná, 81531-980, Curitiba, PR, Brazil

* Corresponding author: malucelli.ts@gmail.com 
Jacquemyn 2010). In this way, studies that integrate plant species pollination and breeding systems are of paramount importance for revealing insights on the persistence of plants in different environments and the identification of species with conservation and restoration potential (e.g. Aguilar et al. 2006; Neuschulz et al. 2016).

It is believed that the presence of generalist plants, with abundant rewards, is important for the establishment and maintenance of the natural processes of restoration (Dixon 2009; Menz et al. 2011). In general, plants that display a greater number of flowers have higher visitation rates (Klinkhamer \& Jong 1990; Mitchell et al. 2004; Grindeland et al. 2005; Makino \& Sakai 2007; Brys \& Jacquemyn 2010). Nonetheless, a greater number of flowers might mean a reduction of, or no effect on, the visitation rate of each individual flower (Klinkhamer \& Jong 1990; Mitchell et al. 2004; Grindeland et al. 2005). Likewise, a high density of flowering individuals in an area might lead to enhanced visitation for each due to facilitation (Kunin 1997; Thompson 2001; Moeller 2004; Makino \& Sakai 2007; Brys \& Jacquemyn 2010; Hegland 2014). Nonetheless, high densities of individuals that overlap in flowering, both in time and space, might cause competition for pollinators, leading to decreased visitation rates per individual (Mustajärvi et al. 2001; Sargent \& Ackerly 2008; Hegland 2014).

Plants in initial restoration areas may become isolated from conspecifics and suffer from a low availability of mates (Scobie \& Wilcock 2009). Moreover, the degradation of the environment in early restoration areas may limit the availability of pollinators (Kremen et al. 2007). In this sense, plants that reproduce through selfing have the advantage of reproductive assurance (Pannell \& Barrett 1998; Moeller \& Geber 2005; Santos et al. 2012), but may suffer disadvantages related to high inbreeding rates (Lande \& Schemske 1985; Herlihy \& Eckert 2002; Maia et al. 2017). On the other hand, self-incompatible plants avoid inbreeding (Lande \& Schemske 1985), but may be unsuccessful in areas with limited availability of pollinators and mates (Pannell \& Barrett 1998; Scobie \& Wilcock 2009). Thus, plants with a mixed breeding system, i.e. involving self-pollination and cross-pollination, and that produce abundant floral resources and attract a great diversity of pollinators, are expected to be good candidates for use in restoration programs

The family Melastomataceae comprises 4,200-4,500 species and is well represented in tropical and subtropical ecosystems of the Americas, where there are approximately 3,000 species (Renner 1993; Goldenberg et al. 2012). Melastomes have been reported as key species for restoration practices due to their seed and seedling ecology (Silveira et al. 2013). In addition, melastomes are important pollen sources for many bee species (Harter et al. 2002). Such bees are adapted to perform buzz pollination, which enables the extraction of pollen by sonication (Buchman 1983) to feed their larvae (Michener 2007). The floral morphology of some species of Melastomataceae, such as the occurrence of poricidal anthers and herkogamy (Renner 1989), suggests that these species do not perform autonomous self-fertilization, and require pollinators for pollen transfer.

The present study investigated the breeding system and pollination biology of Pleroma trichopodum DC. (Melastomataceae) (Fig. 1), which, until recently, was named Tibouchina trichopoda (Meyer et al. 2010). Pleroma trichopodum is a pioneer tree adapted to environments saturated with water (Meyer et al. 2010; Maia et al. 2013), and is abundant in areas undergoing early natural regeneration in southern Brazil (Cardoso 2014; Warring et al. 2016). Although it has potential for use in the restoration of Atlantic Forest, knowledge of its reproductive and pollination biology is incomplete, particularly regarding its pollinators and mating system. For instance, it is known that large floral displays by this species are related to enhanced reproductive success (Maia et al. 2013), but whether this is associated with increased floral visitation is unknown.
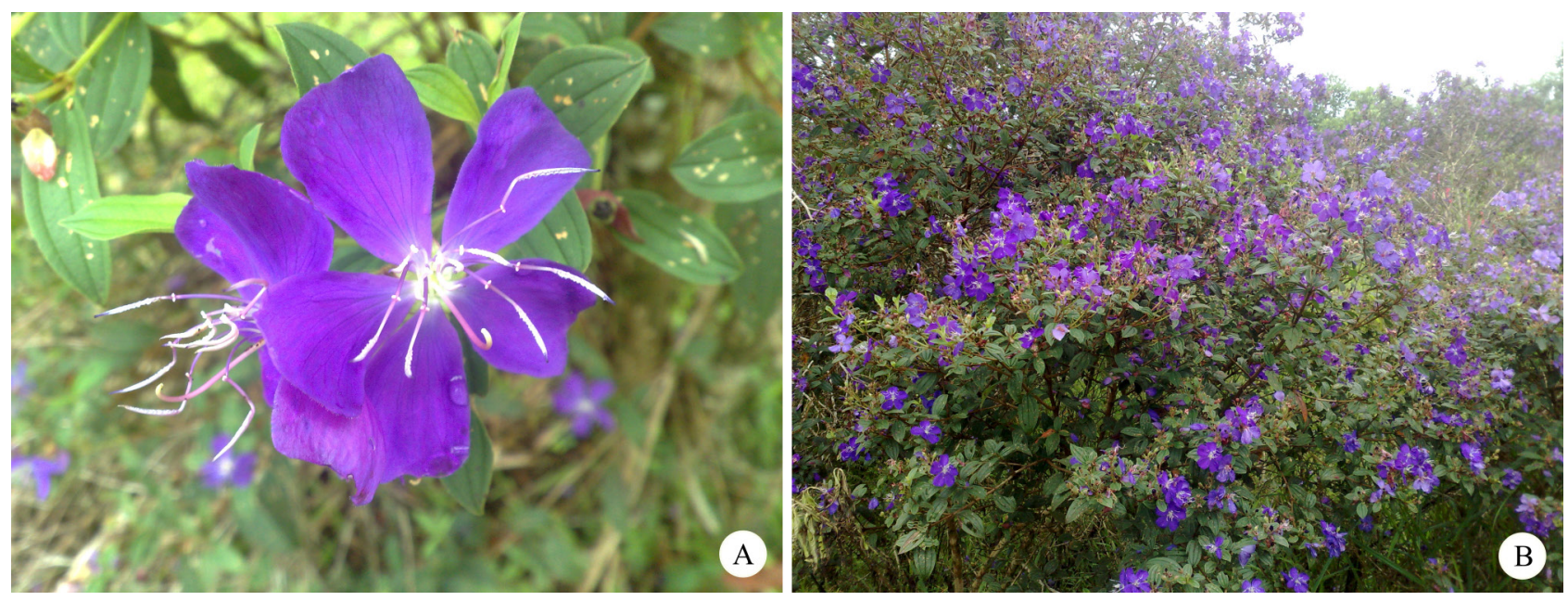

Figure 1. Pleroma trichopodum. A. Flower in detail, showing the poricidal anthers. B. A tree with a large floral display. 
Individuals of $P$. trichopodum occurring in natural regeneration areas were selected to address three major questions: (1) Is $P$. trichopodum dependent on pollinators and mates for reproduction? (2) What are the pollinators of P. trichopodum? (3) Do tree flower-density and floweringtree density of $P$. trichopodum enhance the visitation rate of focal trees and their flowers?

\section{Materials and methods}

\section{Study area}

This study was conducted between September 2009 and February 2010 in areas undergoing early succession in the Guaricica Natural Reserve ( $\left.25^{\circ} 18^{\prime} 50^{\prime \prime} \mathrm{S} 48^{\circ} 41^{\prime} 45^{\prime \prime} \mathrm{W}\right)$. This reserve is located within an environmental protection area (Área de Proteção Ambiental de Guaraqueçaba) in Antonina, on the northern coast of Paraná State, southern Brazil. The climate is subtropical humid, with an average annual precipitation of $2534.5 \mathrm{~mm}$ (Vanhoni \& Mendonça 2008) and an annual average temperature between $20.8^{\circ} \mathrm{C}$ and $22^{\circ} \mathrm{C}$ (Ferretti \& Britez 2006).

\section{Breeding system and floral visitors}

From September 2009 to November 2009 we performed five pollination treatments (Radford et al. 1974): open pollination, in which we labeled buds in pre-anthesis and left them without isolation; autonomous self-pollination, in which we labeled buds in pre-anthesis and isolated them to exclude pollinators; manual self-pollination, in which we transferred pollen manually from one tree to the stigma of flowers of the same tree, isolating them after this procedure; outcrossing, in which we transferred pollen from different trees to the stigma of flowers of a focal tree, isolating the flowers after this procedure; apomixis in which we removed the styles and stamens of buds in pre-anthesis before isolation. We surveyed the treatments throughout one month to assess fruit formation in each of the surveyed trees. The number of flowers varied among treatments, but the minimum was 70 . We used eight trees for the open pollination and autonomous self-pollination treatments and seven trees for the manual self-pollination, outcrossing and apomixis treatments. We calculated fruit set as the ratio between the number of ripened fruits and the number flowers in each treatment. We calculated the independence of fruit set among treatments by Pearson's Chi-squared test using R software (R Core Team 2017). We calculated the Index of Self-Incompatibility (ISI, sensu Bullock 1985) as the fruit-set ratio between manual self-pollination and outcrossing treatments; ISI values higher than 0.25 were interpreted as an indication of selfing (Zapata \& Arroyo 1978). We calculated Reproductive Efficacy (RE; Zapata \& Arroyo 1978; Oliveira \& Gibbs 2000) as the ratio between fruit-set from the open pollination treatment and fruit-set from the outcrossing treatment. Along with the reproductive tests, we performed opportunistic floral visitor observations as well as focal observations in different individuals to assess the complete floral visitor guild. Floral visitors were collected and sent to specialists for identification.

\section{Visitation rate as a function of floral display}

To determine how tree visitation rate (visits per hour on each tree) and flower visitation rate (visits per hour per flower on each tree) varied as a function of the density of flowering trees next to focal trees and the density of flowers displayed by the focal trees, we performed observations on 10 flowering individuals of $P$. trichopodum from November 2009 to February 2010. The focal trees were distributed among six young natural regeneration sites with trees in the same being separated by at least 30 meters. These young successional areas possessed a great abundance of exotic grasses that usually dominated the wetter portions (Ferretti \& Britez 2006; Cardoso 2014). In fact, many of the individual trees we observed were completely surrounded by these grasses. During four months, we performed approximately 10 hours of focal observations for each focal plant for a total of 100 hours of observation. We observed each plant in two bouts, one in the morning (five hours) and one in the afternoon (five hours), but not necessarily on the same day due two logistics and weather conditions. We counted the number of flowering P. trichopodum plants in a circular plot of $15 \mathrm{~m}$ of radius $\left(706.5 \mathrm{~m}^{2}\right)$ around the focal trees to assess the density of flowering trees. To determine the density of flowers in each focal tree we marked an area of $1.20 \times 1.20 \mathrm{~m}\left(1.44 \mathrm{~m}^{2}\right)$ on the north and in the south faces of the plants crown in which we counted the number of flowers and observed pollinator visitation. We switched between north and south face of the crown every 30 minutes of observation.

All floral visitors were collected and sent to specialists for identification. Only visitors that acted as potential pollinators were included in the analysis. We considered as potential pollinators visitors that contacted the flower stigma when collecting pollen from the anthers and visitors that, when releasing the pollen from single anthers, created a pollen cloud that could eventually reach the stigma (Maia et al. 2016). We considered visitors that collected pollen without touching the stigmas as pollen thieves. The number of visits was summed for each tree in each bout. Since each tree was observed during two bouts (one morning and one afternoon), we ended up with 20 replicates. The number of visits during each replicate was divided by five hours to calculate the visitation rate per hour at each tree in a given bout (tree visitation rate). Additionally, we divided this visitation rate by the number of flowers counted on each tree during an observation bout to calculate the flower visitation rate on trees (flower visitation rate). Data for visitation rate, tree flower-density, flowering-tree density, 
hours of observation and observation bout are available as Table $\mathrm{S} 1$ in supplementary material.

To assess the effect of focal tree flower-density and flowering-tree density on tree visitation rate and flower visitation rate, we used Generalized Linear Mixed Models (GLMM), assuming a normal error distribution, performed with the lme4 package (Bates et al. 2015). We used tree visitation rate and flower visitation rate as response variables, tree flower-density and flowering-tree density as fixed predictors, and sites and bout as random factors. Thus, we could account for any lack of independence among replicates at the same site or during the same bout. We scaled the predictor variables (tree flower-density and flowering-tree density) prior to the analysis. We assessed the significance of tree flower-density and flowering-trees density by likelihood ratio tests when dropping each variable from the full model (Campos-Arceiz et al. 2008; Turrini \& Knop 2015), using the car package (Fox \& Weisberg 2011). All the analyses were conducted with the R software ( $R$ Core Team 2017).

\section{Results}

Pleroma trichopodum produced fruits by selfing and outcrossing and did not produce fruits by apomixis and autonomous selfing (Tab. 1). Fruit set was similar among control, selfing and outcrossing treatments $\left(X^{2}=0.17\right.$; $\mathrm{df}=2$; $p>0.05 ;$ Tab. 1 ). The high values for the auto incompatibility index (ISI) suggest selfing for P. trichopodum, while the high values for reproductive efficacy suggest a high efficacy of natural pollination (Tab. 1).

Table 1. Fruit set (sample size) of the four reproductive treatments for Pleroma trichopodum. ISI - Index of Self-Incompatibility. RE -

Reproductive efficacy.

\begin{tabular}{|l|c|}
\hline \multicolumn{1}{|c|}{ Treatment } & Fruit set (number of flowers) \\
\hline Open pollination & $52.5(80)$ \\
\hline Autonomous self-pollination & $0(70)$ \\
\hline Manual self-pollination & $54.7(75)$ \\
\hline Outcrossing & $50.7(73)$ \\
\hline Apomixis & $0(71)$ \\
\hline ISI & 1.08 \\
\hline RE & 1.04 \\
\hline
\end{tabular}

Only bees were recorded on P. trichopodum flowers, eleven of which were pollinators and one of which was a pollen thief (Tab. 2). The behavior of bees of the genera Bombus, Centris, Thygater and Xylocopa was similar. These bees landed on the flower, embraced several anthers and vibrated them, releasing a pollen cloud characteristic of buzz-pollination. The bees of the genus Augochloropsis vibrated one anther at a time, releasing a pollen cloud that eventually could contact the stigma (Maia et al. 2016). Bees of the genus Tetragonisca behaved as pollen thieves, collecting pollen by chewing the top of the anthers.
Flower density of the focal trees ranged from 4.17 to 95.49 flowers per $\mathrm{m}^{2}$, while the flowering-tree density ranged from 0 to 0.06 trees per $\mathrm{m}^{2}$. The GLMM analysis showed that tree visitation rate was significantly affected by tree flower-density but not by flowering-tree density (Fig. 2A, $B, T a b .3)$. The relationship between tree visitation rate and tree flower-density was strongly positive (Fig. 2A, Tab. 3). Nonetheless, neither of the two-predictor variables affected flower visitation rate (Fig. 2C, D, Tab. 3).

Table 2. Floral visitors of Pleroma trichopodum identified as pollinators or pollen thieves.

\begin{tabular}{|l|c|}
\hline \multicolumn{1}{|c|}{ Species } & Visitation type \\
\hline Augochloropsis sp. 1 & pollinator \\
\hline Augochloropsis sp. 2 & pollinator \\
\hline Augochloropsis sp. 3 & pollinator \\
\hline Augochloropsis sp. 4 & pollinator \\
\hline Bombus (Fervidobombus) brasiliensis (Lepeletier, 1836) & pollinator \\
\hline Bombus (Fervidobombus) morio (Swederus, 1787) & pollinator \\
\hline Bombus (Fervidobombus) pauloensis (Friese, 1913) & pollinator \\
\hline Centris (Aphemisia) mocsaryi (Friese, 1899) & pollinator \\
\hline Tetragonisca angustula (Latreille, 1811) & pollen thief \\
\hline Thygater sp. & pollinator \\
\hline Xylocopa (Neoxylocopa) brasilianorum (Linnaeus, 1767) & pollinator \\
\hline Xylocopa (Neoxylocopa) frontalis (Olivier, 1789) & pollinator \\
\hline
\end{tabular}

Table 3. Results of the Generalized Linear Mixed Model using visitation rate per tree and per flower as response variables, tree flower-density and flowering-tree density as fixed predictors, and sites and bout as random factors. The significance of the predictors was assessed by likelihood ratio test (LRT), considering values of $p$ lower than 0.05 as significant. Significant variables are in bold.

\begin{tabular}{|l|c|c|c|c|}
\hline \multirow{2}{*}{ Tree visitation rate } & \multicolumn{2}{|c|}{ GLMM } & \multicolumn{2}{c|}{ Likelihood ratio test } \\
\cline { 2 - 5 } & Coef. & SE & LRT & $\mathbf{p}$ \\
\hline Intercept & 0.640 & 0.137 & & \\
\hline Tree flower-density & $\mathbf{0 . 4 0 2}$ & $\mathbf{0 . 0 9 9}$ & $\mathbf{1 1 . 5 1 9}$ & $<\mathbf{0 . 0 0 1}$ \\
\hline Flowering-tree density & 0.005 & 0.102 & 0.002 & 0.964 \\
\hline Flower visitation rate & & & & \\
\hline Intercept & 0.009 & 0.003 & & \\
\hline Tree flower-density & -0.004 & 0.003 & 1.879 & 0.170 \\
\hline Flowering-tree density & 0.001 & 0.003 & 0.027 & 0.870 \\
\hline
\end{tabular}

\section{Discussion}

Pleroma trichopodum is completely dependent on pollinators for reproduction, which are attracted by large floral displays. Nonetheless, the possibility of self-pollination reduces the necessity of mates for its reproduction.

The strong effect of tree flower-density on tree visitation rate shows that, for P. trichopodum, the investment of energy into big floral displays is a successful strategy for attracting pollinators. The benefit of larger floral displays is associated with the cognition ability of bees (Schiestl \& Johnson 2013), for which visual cues might enhance their efficiency (Kunze 
\& Gumbert 2001). The lack of a relationship between tree visitation rate and density of flowering conspecifics could be related to the absence of competition or facilitation. Another possibility is that both processes occur at a same time. If the latter is true, the lack of a pattern in the analysis could be due to the fact that one pattern confounds the other, thus precluding the identification of either. Although an enhanced display of flowers attracted more pollinators to focal trees, this was not related to variation in visitation rate per flower (Mitchell et al. 2004), as previous detected for other species (Klinkhamer \& Jong 1990; Grindeland et al. 2005). In this way, we did not confirm that enhanced fruiting success in $P$. trichopodum plants with more flowers, as detected in a previous study (Maia et al. 2013), could be due to enhaced visitation of pollinators to each flower.
Most of the bee species that were found attracted to P. trichopodum are common for species of the Melastomataceae genus Tibouchina (genus to which P. trichopodum belonged until recently; Pereira et al. 2011; Franco et al. 2011; Brito \& Sazima 2012). Several floral visitors of one species of Tibouchina (T. pulchra), studied by Pereira et al. (2011), belonged to three genera also found visiting P. trichopodum, and vary in their relative lengths (size). This trait variation could indicate a certain degree of functional complementarity and enhance the reproductive success of plant communities (Fontaine et al. 2006; Albrecht et al. 2012). The enhanced attractiveness of high floral display plants to different bees shows that these trees might function as islands of resources (Brito et al. 2015) in areas where exotic herbs are dominant. Although we could not see a clear pattern of facilitation, by attracting many pollinators with different pollination traits,
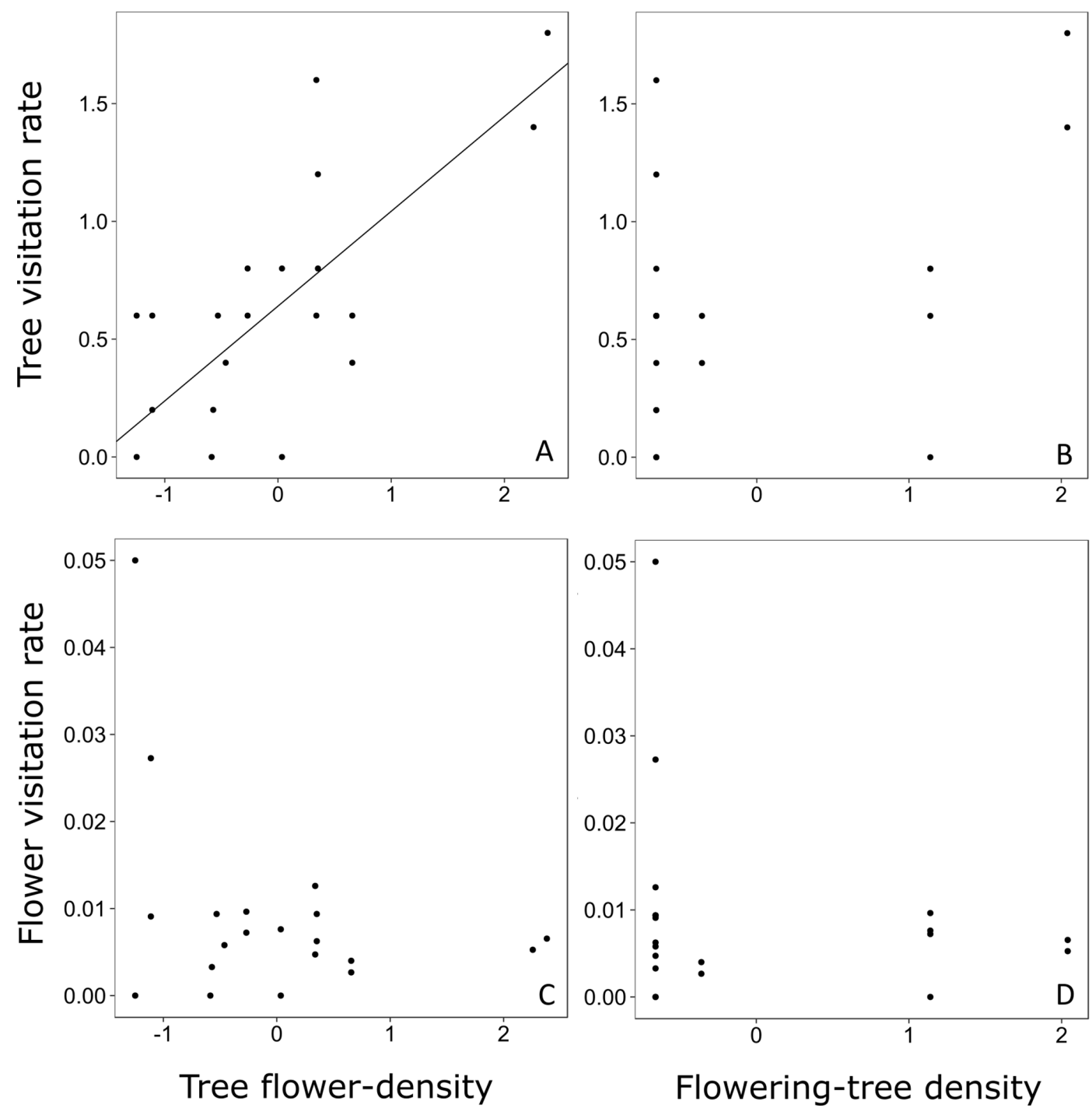

Figure 2. Relationship between tree visitation rate and tree flower-density $(\mathbf{A})$ and flowering-tree density (B). Relationship between flower visitation rate and tree flower-density $(\mathbf{C})$ and flowering-tree density $(\mathbf{D})$. Tree visitation rate is the number of visits per hour on each tree in a given bout of focal observation. Flower visitation rate is the tree visitation rate divided by the number of flowers of each tree in a given bout. 
these plants might enhance the chance of pollination for neighbor plants. It is known that the presence of isolated trees in abandoned pastures facilitates the establishment of other species, by reducing competition with exotic grasses and by enhancing the arrival of seeds that are dispersed by animals (Zwiener et al. 2014). Here we argue that $P$. trichopodum might also provide pollinator assurance to plants that are growing under its canopy or in its proximity, thus functioning as a magnet species (Molina-Montenegro et al. 2008). Furthermore, previous studies with P. trichopodum report two flowering seasons: an extended flowering period with scattered flowering individuals during the less rainy season; and a brief flowering period with a high density of flowering individuals during the hot, rainy season (Maia et al. 2013). In this way, P. trichopoda might also be considered a bridging plant since it provides floral resources over a long temporal span and in periods of the year with contrasting climates (Dixon 2009).

Pleroma trichopodum reproduces by a mix of selfing and cross-pollination. The high value of the ISI index indicates that self-pollination by this species is highly efficient, which is common among other species of Melastomataceae (Goldenberg \& Shepherd 1998; Franco et al. 2011; Pereira et al. 2011; Maia et al. 2016). The independence from mates for the exchange of pollen for reproduction through selfing, confers this plant with a good capacity to colonize new areas (Holsinger 2000), which is reflected in its presence in early succession areas (Cardoso 2014). Nonetheless, autonomous selfing does not occur, probably because of the spatial separation between the anthers and the stigma (herkogamy), and because of the tiny pore of the anthers (Renner 1989). Thus, $P$. trichopodum is entirely dependent on bee pollination for its reproduction. This dependence might lead to limited pollination in areas where the availability of bees is low (Brito \& Sazima 2012). Still, the high reproductive efficacy $(\mathrm{RE})$ suggests that these bees are efficient pollinators and relatively abundant and active in our study area.

The possibility of selfing and the attraction of a diverse guild of pollinators, as well as the adaptation to wet soils, show that $P$. trichopodum has potential for use in the assisted restoration of areas where the soil remains soggy most of the time (Ferretti \& Britez 2006). Since tree visitation rate increases with the number of flowers on the tree, but not with tree density, spaced planting of vigorous or more developed individuals is a better strategy to attract pollinators to an area than planting clumped small or young individuals. These sparse individuals can act as steppingstones and increase pollen dispersal between different areas (Kitamoto et al. 2006).

Our study provided valuable biological information on an abundant pioneer species of the Atlantic Forest of southern Brazil. Pleroma trichopodum revealed characteristics of a good colonizer that deserves further study for use in restoration purposes. By studying bee visitation rate on individual plants, we reinforced the hypothesis that these insects are mostly attracted by the abundance of floral resources. Nonetheless, for P. trichopodum the effect of conspecific plants remains unanswered.

\section{Acknowledgements}

We thank the Universidade Federal do Paraná (UFPR, Federal University of Paraná) for the opportunity to do this research. We are grateful to Aline da DanieliSilva, Jana Magaly de Souza for the helpful comments to this manuscript. We also thank SPVS (Sociedade para Proteção da Vida Selvagem e Educação Ambiental) for the logistical support at the Reserva Natural Guaricica and Reserva Natural das Águas. This research was supported by CNPq (Grant no. 475127/2008 0 and PQ scholarship 309453/2013-5 to IGV).

\section{References}

Aguilar R, Ashworth L, Galetto L, Aizen MA. 2006. Plant reproductive susceptibility to habitat fragmentation: Review and synthesis through a meta-analysis. Ecology Letters 9: 968-980.

Aide MT, Zimmerman JK, Pascarella JB, Rivera L, Marcano-Vega H. 2000. Forest regeneration in a chronosequence of tropical abandoned pastures: Implications for restoration ecology. Restoration Ecology 8: 328-338.

Albrecht M, Schmid B, Hautier Y, Muller CB. 2012. Diverse pollinator communities enhance plant reproductive success. Proceedings of the Royal Society B 279: 4845-4852.

Ashman T, Knight TM, Steets JA, et al. 2004. Pollen limitation of plant reproduction: ecological and evolutionary causes and consequences. Ecology 85: 2408-2421.

Ayasse M, Arroyo J. 2011. Pollination and plant reproductive biology. Plant Biology 13: 1-6.

Bates D, Mächler M, Bolker B, Walker S. 2015. Fitting linear mixed-effects models using lme4. Journal of Statistical Software 67: 1-48.

Bond WJ. 1994. Do mutualisms matter? Assessing the impact of pollinator and disperser disruption on plant extinction. Philosophical Transactions of the Royal Society B 344: 83-90.

Brito VLG, Sazima M. 2012. Tibouchina pulchra (Melastomataceae): Reproductive biology of a tree species at two sites of an elevational gradient in the Atlantic rainforest in Brazil. Plant Systematics and Evolution 298: 1271-1279.

Brito VLG, Weynans K, Sazima M, Lunau K. 2015. Trees as huge flowers and flowers as oversized floral guides: the role of floral color change and retention of old flowers in Tibouchina pulchra. Frontiers in Plant Science 6: 362 .

Brys R, Jacquemyn H. 2010. Floral display size and spatial distribution of potential mates affect pollen deposition and female reproductive success in distylous Pulmonaria officinalis (Boraginaceae). Plant Biology 12: 597-603.

Buchman SL. 1983. Buzz pollination in Angiosperms. In: Jones CE, Little RJ. (eds.) Handbook of experimental pollination biology. New York, Van Nostrand Reinhold. p. 73-113.

Bullock SH. 1985. Breeding systems in the flora of a tropical deciduous forest in Mexico. Biotropica 17: 287-301.

Campos-Arceiz A, Larrinaga AR, Weerasinghe UR, et al. 2008. Behavior rather than diet mediates seasonal differences in seed dispersal by Asian elephants. Ecology 89: 2684-2691.

Cardoso FCG. 2014. A estruturação de comunidades vegetais em áreas sucessionais da floresta atlântica em diferentes tipos de solo. $\mathrm{PhD}$ Thesis, Universidade Federal do Paraná, Curitiba. 


\section{Tiago Simões Malucelli, Fabiano Rodrigo Maia and Isabela Galarda Varassin}

Cheung KC, Marques MCM, Liebsch D. 2009. Relação entre a presença de vegetação herbácea e a regeneração natural de espécies lenhosas em pastagens abandonadas na Floresta Ombrófila Densa do Sul do Brasil. Acta Botanica Brasilica 23: 1048-1056.

Dixon KW. 2009. Pollination and restoration. Science 325: 571-573.

Ferretti AR, Britez RM. 2006. Ecological restoration, carbon sequestration and biodiversity conservation: The experience of the Society for Wildlife Research and Environmental Education (SPVS) in the Atlantic Rain Forest of Southern Brazil. Journal of Nature Conservancy 14: 249-259.

Fontaine C, Dajoz I, Meriguet J, Loreau M. 2006. Functional diversity of plant-pollinator interaction webs enhances the persistence of plant communities. PLoS Biology 4: e1. doi: 10.1371/journal.pbio.0040001

Fox J, Weisberg S. 2011. An $\{\mathrm{R}\}$ companion to applied regression. 2nd. edn. Thousand Oaks, Sage.

Franco AM, Goldenberg R, Varassin IG. 2011. Pollinator guild organization and its consequences for reproduction in three synchronopatric species of Tibouchina (Melastomataceae). Revista Brasileira de Entomologia 55: 381-388.

Goldenberg R, Baumgratz JFA, Souza MLDR. 2012. Taxonomia de Melastomataceae no Brasil: retrospectiva, perspectivas e chave de identificação para os gêneros. Rodriguésia 63: 145-161.

Goldenberg R, Shepherd GJ. 1998. Studies on the reproductive biology of Melastomataceae in "cerrado" vegetation. Plant Systematics and Evolution 211: 13-29.

Grindeland JM, Sletvold N, Ims RA. 2005. Effects of floral display size and plant density on pollinator visitation rate in a natural population of Digitalis purpurea. Functional Ecology 19: 383-390.

Harter B, Leistikow C, Wilms W, Truylio B, Engels W. 2002. Bees collecting pollen from flowers with poricidal anthers in a south Brazilian Araucaria forest: A community study. Journal of Apicultural Research 41: 9-16.

Hegland SJ. 2014. Floral neighbourhood effects on pollination success in red clover are scale-dependent. Functional Ecology 28: 561-568.

Herlihy CR, Eckert CG. 2002. Genetic cost of reproductive assurance in a self-fertilizing plant. Nature 416: 320-323.

Holsinger KE. 2000. Reproductive systems and evolution in vascular plants. Proceedings of the National Academy of Sciences 97: 7037-7042.

Kitamoto N, Ueno S, Takenaka A, Tsumura Y, Washitani I, Ohsawa R. 2006. Effect of flowering phenology on pollen flow distance and the consequences for spatial genetic structure within a population of Primula sieboldii (Primulaceae). American Journal of Botany 93: 226-233.

Klinkhamer PGL, Jong TJ. 1990. Effects of plant size, plant density and sex differential nectar reward on pollinator visitation in the protandrous Echium vulgare (Boraginaceae). Oikos 57: 399-405.

Kremen C, Williams NM, Aizen MA, et al. 2007. Pollination and other ecosystem services produced by mobile organisms: a conceptual framework for the effects of land-use change. Ecology Letters 10: 299-314.

Kunin WE. 1997. Population size and density effects in pollination: Pollinator foraging and plant reproductive success in experimental arrays of Brassica kaber. Journal of Ecology 85: 225-234.

Kunze J, Gumbert A. 2001. The combined effect of color and odor on flower choice behavior of bumble bees in flower mimicry systems. Behavioral Ecology 12: 447-456.

Lande R, Schemske D. 1985. The evolution of self-fertilization and inbreeding depression in plants. Evolution 39: 24-40.

Maia FR, Malucelli TS, Varassin IG. 2013. Ecological factors affecting the fruiting success of a Tibouchina trichopoda (DC.) Baill. (Melastomataceae) flower. Acta Botanica Brasilica 27: 142-146.

Maia FR, Sujii PS, Silva-Pererira V, Goldenberg R. 2017. Naturally fragmented and isolated distribution in subtropical grassland patches affects genetic diversity and structure at different spatial scales: The case of Tibouchina hatschbachii, an endemic shrub from Brazil. American Journal of Botany 104: 1867-1877.

Maia FR, Varassin IG, Goldenberg R. 2016. Apomixis does not affect visitation to flowers of Melastomataceae, but pollen sterility does. Plant Biology 18: 132-138.
Makino TT, Sakai S. 2007. Experience changes pollinator responses to floral display size: From size-based to reward-based foraging. Functional Ecology 21: 854-863.

Mayer C, Adler L, Armbruster W, et al. 2011. Pollination ecology in the $21^{\text {st }}$ Century: key questions for future research. Journal of Pollination Ecology 3: 8-23.

Menz MHM, Phillips RD, Winfree R, et al. 2011. Reconnecting plants and pollinators: Challenges in the restoration of pollination mutualisms. Trends in Plant Science 16: 4-12.

Meyer FS, Guimarães PJF, Goldenberg R. 2010. Tibouchina (Melastomataceae) do estado do Paraná, Brasil. Rodriguésia 61: 615-638.

Michener CD. 2007. Bees of the world. 2nd. edn. Baltimore, The Johns Hopkins University Press.

Mitchell RJ, Karron JD, Holmquist KG, Bell JM. 2004. The influence of Mimulus ringens floral display size on pollinator visitation patterns. Functional Ecology 18: 116-124.

Moeller DA. 2004. Facilitative interactions among plants via. Ecology 85: 3289-3301.

Moeller DA, Geber MA. 2005. Ecological context of the evolution of selfpollination in Clarkia xantiana: Population size, plant communities, and reproductive assurance. Evolution 59: 786-799.

Molina-Montenegro MA, Badano EI, Cavieres LA. 2008. Positive interactions among plant species for pollinator service: assessing the "magnet species" concept with invasive species 117: 18331839.

Mustajärvi K, Siikamäki P, Rytkönen S, Lammi A. 2001. Consequences of plant population size and density for plant-pollinator interactions and plant performance. Journal of Ecology 89: 80-87.

Neuschulz EL, Mueller T, Schleuning M, Böhning-Gaese K. 2016. Pollination and seed dispersal are the most threatened processes of plant regeneration. Scientific Reports 6: 29839. doi:10.1038/srep29839

Oliveira PE, Gibbs PE. 2000. Reproductive biology of woody plants in a cerrado community of Central Brazil. Flora 195: 311-329.

Ollerton J, Winfree R, Tarrant S. 2011. How many flowering plants are pollinated by animals? Oikos 120: 321-326.

Pannell JR, Barrett SCH. 1998. Baker's law revisited: Reproductive assurance in a metapopulation. Evolution 52: 657-668.

Pereira AC, Silva JB, Goldenberg R, Melo GAR, Varassin IG. 2011. Flower color change accelerated by bee pollination in Tibouchina (Melastomataceae). Flora 206: 491-497.

R Core Team. 2017. R: A language and environment for statistical computing. Vienna. http//www.R-project.org/

Radford AE, Dickison WC, Massey JR, Bell RC, Seiler MS. 1974. Vascular plant systematics. New York, Harper and Row.

Renner SS. 1989. A survey of reproductive biology in neotropical Melastomataceae and Memecylaceae. Annals of the Missouri Botanical Garden 76: 496-518.

Renner SS. 1993. Phylogeny and classification of the Melastomataceae and Memecylacea. Nordic Journal of Botany 3: 519-540.

Rodrigues RR, Lima RAF, Gandolfi S, Nave AG. 2009. On the restoration of high diversity forests: 30 years of experience in the Brazilian Atlantic Forest. Biological Conservation 142: 1242-1251.

Santos APM, Fracasso CM, Santos ML, Romero R, Sazima M, Oliveira PE. 2012. Reproductive biology and species geographical distribution in the Melastomataceae: a survey based on New World taxa. Annals of Botany 110: 667-679.

Sargent RD, Ackerly DD. 2008. Plant-pollinator interactions and the assembly of plant communities. Trends in Ecology and Evolution 23: $123-130$

Schiestl FP, Johnson SD. 2013. Pollinator-mediated evolution of floral signals. Trends in Ecology and Evolution 28: 307-315.

Scobie AR, Wilcock CC. 2009. Limited mate availability decreases reproductive success of fragmented populations of Linnaea borealis, a rare, clonal self-incompatible plant. Annals of Botany 103: 835-846.

Silveira FAO, Fernandes GW, Lemos-Filho JP. 2013. Seed and seedling ecophysiology of neotropical Melastomataceae: implications for conservation and restoration of savannas and rainforests. Annals of the Missouri Botanical Garden 99: 82-99. 
Breeding system and pollination of Pleroma trichopodum DC. (Melastomataceae): a potential species for the restoration of Atlantic Forest in southern Brazil

Thompson JD. 2001. How do visitation patterns vary among pollinators in relation to floral display and floral design in a generalist pollination system? Oecologia 126: 386-394.

Turrini T, Knop E. 2015. A landscape ecology approach identifies important drivers of urban biodiversity. Global Change Biology 21: 1652-1667.

Vanhoni F, Mendonça F. 2008. O clima do litoral do estado do Paraná. Revista Brasileira de Climatologia 3: 49-63.

Warring B, Cardoso FCG, Marques MCM, Varassin IG. 2016. Functional diversity of reproductive traits increases across succession in the Atlantic forest. Rodriguésia 67: 321-333.

Young TP. 2000. Restoration ecology and conservation biology. Biological Conservation 92: 73-83.

Zapata TR, Arroyo MTK. 1978. Plant reproductive ecology of a secondary deciduous tropical forest in Venezuela. Biotropica 10: 221-230.

Zwiener VP, Cardoso FCG, Padial AA, Marques MCM. 2014. Disentangling the effects of facilitation on restoration of the Atlantic Forest. Basic and Applied. Ecology 15: 34-41. 